Article

\title{
A Proposal for Public Health Information System-Based Health Promotion Services
}

\author{
Kichan Yoon ${ }^{1}$, Sewon Park ${ }^{2}\left(\mathbb{D}\right.$, Solji Choi ${ }^{1, *,+}$ (†) and Munjae Lee ${ }^{2, *,+}$ (i) \\ 1 Social Security Information Institute, Social Security Information Service, Seoul 04554, Korea; \\ ykichan@ssis.or.kr \\ 2 Department of Medical Device Management and Research, SAIHST, Sungkyunkwan University, \\ Seoul 06355, Korea; se10919@g.skku.edu \\ * Correspondence: choisolji1223@gmail.com (S.C.); emunjae@skku.edu (M.L.) \\ + These authors contributed equally to this work.
}

Received: 21 February 2020; Accepted: 13 March 2020; Published: 15 March 2020

\begin{abstract}
This study aims to examine the current status and utilization of 22 health promotion projects that use the health care information system. We investigate the health promotion examination results for a counseling project held at health centers, which use information connected with the Health Insurance Corporation. First, we review the status of 22 health promotion projects, including 13 integrated health promotion projects and 9 other health promotion projects. Next, we examine the linkages between the 22 projects and other health promotion systems. Consequently, despite accumulating vast amounts of data, only 10 places could be linked to health promotion data in the health and medical information system; the Social Security Information Service was the only exception to this trend. The Public Health Information System (PHIS) had the lowest data utilization rate in the project. The study results show that it is necessary to utilize data from local health and medical institutions in order to provide information system-based health promotion services. In particular, it seems to be effective when health and medical institutions provided various counseling services and other linked services to local residents in connection with the Korea Health Insurance Corporation's health examination results.
\end{abstract}

Keywords: health promotion project; public health information system; health promotion services; primary care; Korea

\section{Introduction}

As of October 2019, Korea has become an aged society, where more than $14 \%$ of the population accounts for elderly people over 65 years old. Accordingly, people's life expectancy, as well as their interest in health, has been increasing. In just five years, life expectancy in Korea increased from 80.87 years old to 82.7 years old in 2017 [1,2]. People's right to health can be seen as a fundamental human right to be guaranteed by the nation and simultaneously as a base element for improving quality of life. It is stipulated in the National Health Promotion Act that the state should promote the health of its people by creating conditions in which people can practice their own healthy lives [3,4].

Community-customized health care services are required to extend healthy lives and to guarantee the right to health. The Alma Ata Declaration hosted by the World Health Organization (WHO), established that society and communities affect health and illness [5]. Therefore, for effective health care, customized services should be provided according to the environment of residential districts and an analysis of their current status. In addition, since there is an increasing demand for health care services by each life cycle stage, health care customized to each stage of life should also be provided for health promotion projects executed by the communities' health centers [6-8]. 
Particularly in rural areas where the elderly population is concentrated, there are considerable shortages in the infrastructure and support policies needed to satisfy their health needs. Accordingly, because medical blind spots are likely to occur, due to aging, the importance of primary care that can immediately respond to this has been on the rise [9-11]. In order to reduce medical blind spots in this era of aging, the Ministry of Health and Welfare is developing various health promotion projects centered on health centers (branch offices) and health care centers, among others [12].

To provide community-based health services, the integrated health promotion project is executed through the Public Health Information System (PHIS). Thereby, various health promotion data for each project have been accumulated, and the applicability of such data is of paramount importance [13-15]. Nevertheless, although health promotion data on 22 projects are accumulated on the PHIS, health promotion projects are not helpful in improving the effectiveness, due to the lack of linked application between projects. Therefore, the health examination result counseling service has been conducted since February 2019, which links the health examination results, annually implemented by the National Health Insurance Corporation, with the health promotion program of the Social Security Information Service.

Therefore, the purpose of this study is as follows: 1) to examine the linked status of the Regional Public Health Information System (PHIS), currently operated by the Social Security Information Service; and 2) to analyze the results of the health examination result counseling service-the health promotion data-linked project. By addressing these two research questions, we intend to contribute to improving the health level of local residents through the linked actions with health examination data.

\section{Materials and Methods}

For the data collection, we utilized the manual of social services performed by the Social Security Information Service (SSIS) and secondary data quantified on the basis of the report analyzing the results. The PHIS is operated by the SSIS. It includes a system for operating a total of 22 projects, including the integrated health promotion project.

We will check whether the input data and performance data for the 22 projects in the health promotion project are consistent and investigate the services that could be provided for local communities and residents, through cases studies, if health promotion data is actually utilized. For this purpose, we investigated the health promotion examination results of the counseling project at health centers, which used information connected with the Health Insurance Corporation.

\subsection{Health Promotion Project}

Health promotion is a positive concept of health, which can be seen as an effort to maintain and promote human health $[16,17]$. The meaning of health refers to a good physical state where one is able to participate in social activities, rather than feeling inconvenient in daily life or experiencing negative effects to life expectancy, due to chronic diseases or accidents [18]. The concept of health promotion was defined by the Ottawa Charter of WHO in 1986 as the process of cultivating humans' ability to strengthen their control of health and to improve their health level [19].

The determinants of health are changing from the approach of finding the causes in diseases or human behaviors to social and environmental approaches. Behavior-based approaches focus on changing individual knowledge, attitudes, and behavior; social and environmental approaches are interested in community-based environments, institutions, and policies, emphasizing participation in health promotion activities, cooperation with other sectors, and various other strategies [20-22].

The health promotion project aims to improve the felt-sense level and health behavior of local residents by making local governments promote the projects [11,23]. Central and local governments should endeavor together to achieve the goals of the Health Plan (HP) and to develop health promotion projects connected with different regional properties and residents' needs [24].

The ultimate purpose of the health promotion project lies in improving the health and health equity of the residents, adopting four strategies to accomplish this. First, it carries out programs based on the 
health problems of local communities and the local health environment through the development of different specialized projects. Second, the state and municipalities share roles based on the goals of HP (Health Plan) 2020. Third, by strengthening efficiency, autonomy, and responsibility, each program's budget and manpower will be planned according to the local conditions, and a performance-oriented evaluation system will be established. Fourth, the connection and cooperation with local communities should be reinforced by the vitalization of communication, and the participation of residents in health policy development should be invigorated [25,26].

Local health and medical institutions (health care centers, public health centers, branch offices of health centers, and healthy life supporting centers), established by local governments on the basis of the Regional Public Health Act and the enforcement regulations of the Special Measures Act for Health Care in Agricultural and Fishing Villages, are enforcing the health promotion projects for local residents. However, health care centers are subject to the Special Act on Farming and Fishing Villages. The main projects consist of 13 community-integrated health promotion projects and nine other health promotion projects $[27,28]$.

The community-integrated health promotion projects include a total of 13 programs, such as smoking prohibition, sobriety, physical activity, nutrition, preventive management of obesity, oral health, preventive management of cardiovascular and cerebrovascular diseases, oriental medicine health promotion, preventive management of atopy and asthma, maternal and child health (specialized in mothers and children), dementia management, community-based rehabilitation, and visiting health care. Other health promotion projects include mental health project management, health project management for the elderly, health examination results counseling, health center denture program, tuberculosis management, Hansen's disease management, sexually transmitted infection management, maternal and child health program (subfertility and premature babies), vaccination, and so forth [28,29].

\subsection{Performance System of Health Promotion Project}

\subsubsection{Central Health Institution}

Health promotion projects are divided into local health care policy-making activities; actual activities, such as health projects, health care, and public health administrations; and supporting activities, including local health care informatization. Policy making is established throughout the entire process of the planning, implementation, support, and performance management of policies. The Ministry of Health and Welfare and the Korea Health Promotion Institute play a role in policy making, and the Korea Health Promotion Institute enforces and supports these policies. In the actual activities, local health and medical institutions execute health projects, health care, and public health administration in collaboration with local governments via the planning (supporting) of the Ministry of Health and Welfare and the Korea Health Promotion Institute. In the case of the informatization work for the health promotion project, the PHIS of the Social Security Information Service, the Korea Health Promotion Institute, the Korea Centers for Disease Control and Prevention, and so forth, are providing supporting activities [30,31]

For health services related to health promotion, the Ministry of Health and Welfare and the Korea Health Promotion Institute are in charge of policy making; the enforcement of the health services is divided into planning, execution, and performance management, where each main agent plays its own role. The planning of the health service is mainly undertaken by the Health Policy Division of the Ministry of Health and Welfare, the Korea Health Promotion Institute, and so forth, but local governments, public health centers (health and medical centers), or the like are also in charge of the planning, and the National Rehabilitation Center implements the planning work related to rehabilitation projects for the disabled. The execution of health services is undertaken by local health and medical institutions, mainly by public health centers (health and medical centers), health care centers, and health promotion centers. In the meantime, the performance management for health services is evaluated by local governments and public health centers [32-34]. (Figure 1). 


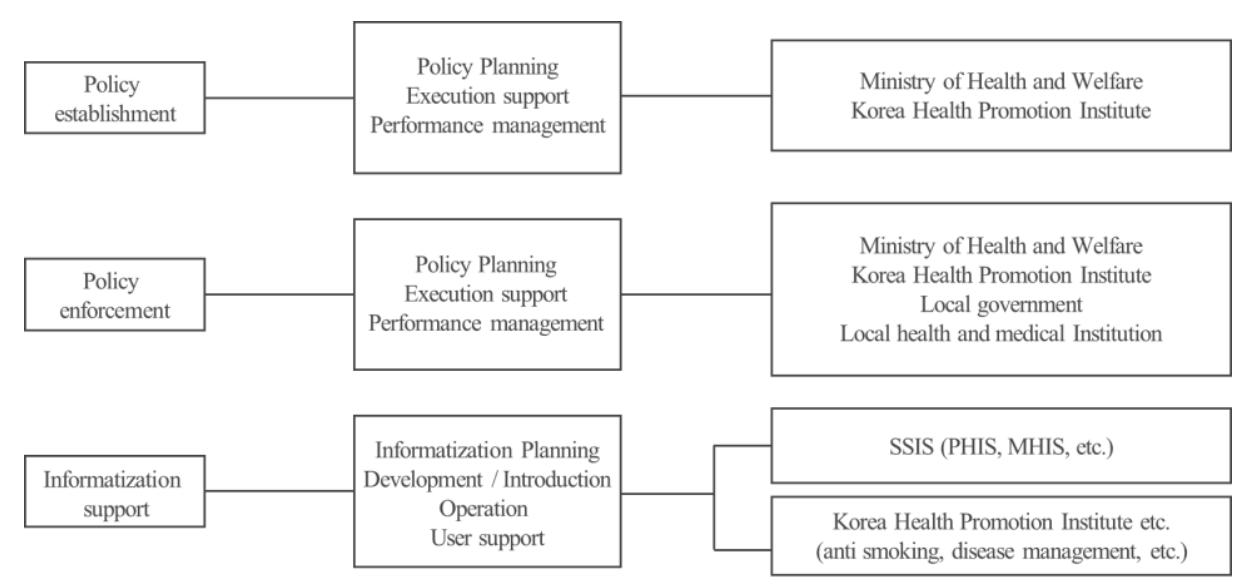

Figure 1. Health promotion projects structure and performance system.

The informatization of health services for health promotion is mainly undertaken by the SSIS through the PHIS. However, the smoking prohibition information system and mobile health care are implemented by the Korea Health Promotion Institute; the infectious disease management and vaccination through the disease health integrated information system is conducted by the Korea Centers for Disease Control and Prevention; and the health examination system is executed by the National Health Insurance Corporation [35].

\subsubsection{Local Health Institution}

Local health and medical institutions performing health promotion projects can be established in accordance with the Regional Public Health Act and the Special Measures Act for Health Care in Agricultural and Fishing Villages, to which each task and function is given. Types of local health and medical institutions include public health centers, health and medical institutions, branch offices of health centers, and healthy life support centers, in accordance with the Regional Public Health Act. Health care centers are established under the Special Measures Act for Health Care in Agricultural and Fishing Villages, providing health and medical care services to vulnerable areas lacking health care. Public health centers and health center branch offices can be established by the ordinances of local governments or through the approval of the Ministry of Health and Welfare.

In the case of the total number of users spent using local health and medical institutions, the number of people participating in the health service for health promotion was more than double that of health care. Particularly, when duplicated people were removed, the number of actual user spent using health care included 2,774,080 people, which is one third that $(7,214,215$ people) of the health service. Therefore, it can be recognized that all of these health promotion projects have been accumulating their results via the information system (Table 1). 
Table 1. Use of local health and medical institutions (2018).

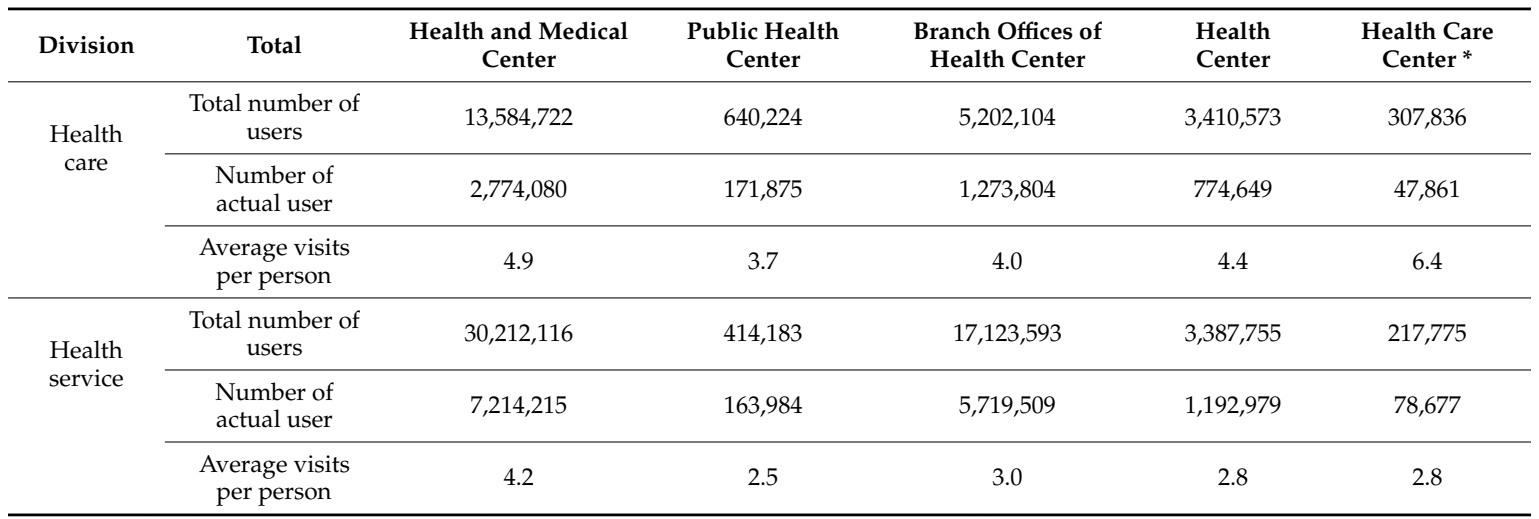

* The health care center is the health and medical institution which is established and operated in vulnerable areas of health care to perform both medical treatments and projects.

\subsection{Outcomes of Integrated Health Promotion Projects in Community}

In terms of the integrated health promotion projects in community, the project was implemented in a total of 12 areas, including sobriety, physical activity, nutrition, obesity, and oral health. Among the 12 integrated health promotion projects in each community, the project that had the largest total number of users from participants from January to November 2018 was the visiting health care project with a total of 1,051,938 people. It was followed by the preventive management project of cardiovascular and cerebrovascular diseases with a total number of users from 845,188 participants, and the dementia management project had 719,673 participants. The details are listed below in Table 2 .

Table 2. Community integrated health projects.

\begin{tabular}{|c|c|c|c|c|}
\hline & Project Contents & $\begin{array}{l}\text { Implementing } \\
\text { Agency }\end{array}$ & $\begin{array}{c}\text { Actual } \\
\text { User }\end{array}$ & Total Users \\
\hline $\begin{array}{l}\text { Sobriety } \\
\text { (1) }\end{array}$ & $\begin{array}{c}\text { Sobriety education \& publicity } \\
\text { Early screening, counseling, and request for high risk } \\
\text { drinkers }\end{array}$ & 31 & 7987 & 10,962 \\
\hline $\begin{array}{l}\text { Physical activity } \\
\text { (2) }\end{array}$ & $\begin{array}{c}\text { Providing education and programs for each life cycle stage } \\
\text { Chronic disease prevention and health care } \\
\text { Publicity \& campaign } \\
\text { Environment creation project } \\
\text { Reinforcement of linkage with community and nutrition } \\
\text { management project }\end{array}$ & 396 & 192,368 & 394,101 \\
\hline \multirow[t]{2}{*}{$\begin{array}{l}\text { Nutrition } \\
\text { (3) }\end{array}$} & $\begin{array}{c}\text { Education promotion on environment creation for healthy } \\
\text { dietary life practice } \\
\text { Life-cycle nutrition management project } \\
\text { Chronic disease prevention and nutrition management } \\
\text { project }\end{array}$ & 150 & 84,565 & 136,123 \\
\hline & Nutrition plus project & 256 & 217,223 & 513,584 \\
\hline $\begin{array}{l}\text { Obesity } \\
\text { (4) }\end{array}$ & $\begin{array}{l}\text { Publicity and campaigns, chronic disease prevention and } \\
\text { obesity management program, resident education program, } \\
\text { and obesity prevention program for vulnerable classes }\end{array}$ & 0 & 0 & 0 \\
\hline $\begin{array}{l}\text { Oral health } \\
\text { (5) }\end{array}$ & $\begin{array}{l}\text { Oral health promotion - Oral health education and publicity, } \\
\text { establishment and operation of school tooth-brushing } \\
\text { facilities, fluoride mouth rinsing, and water fluoridation } \\
\text { adjusting program } \\
\text { Oral-preventive treatment - Fluoride application and } \\
\text { scaling for the elderly, fluoride application for children, and } \\
\text { support project for dental health mobile clinic vehicles } \\
\text { Treatment project for oral health promotion \& oral disease } \\
\text { prevention Installation \& operation of oral health center } \\
\text { (oral health room) in health centers, installation \& operation } \\
\text { of school oral health room, and operation of oral care center } \\
\text { for the disabled }\end{array}$ & 508 & 589,856 & 837,743 \\
\hline
\end{tabular}


Table 2. Cont.

\begin{tabular}{|c|c|c|c|c|}
\hline $\begin{array}{l}\text { Preventive } \\
\text { management for } \\
\text { cardio-cerebrovascular } \\
\text { disease } \\
\text { (6) }\end{array}$ & $\begin{array}{l}\text { Preventive management project for cardiovascular disease } \\
\text { at public health center of cities and countries } \\
\text { Community PR project, early detection project for patients } \\
\text { Registration management project for hypertension, } \\
\text { diabetes, and dyslipidemia patients } \\
\text { Matching project between central promotional contents and } \\
\text { local promotional media } \\
\text { Local self-education and promotion project by using central } \\
\text { promotional contents }\end{array}$ & 1163 & 845,188 & $2,852,252$ \\
\hline $\begin{array}{l}\text { Health promotion } \\
\text { of oriental medicine } \\
\text { (7) }\end{array}$ & $\begin{array}{l}\text { Operation of oriental medicine health promotion programs } \\
\text { Operating consulting rooms of oriental medicine }\end{array}$ & 346 & 60,223 & 189,216 \\
\hline $\begin{array}{l}\text { Specialized in } \\
\text { women and } \\
\text { children } \\
\text { (8) }\end{array}$ & $\begin{array}{c}\text { Registration \& management of pregnant women Maternity } \\
\text { health care } \\
\text { Support of iron pills, Support of folic acid, postpartum } \\
\text { depression management, and health promotion of fertile } \\
\text { women } \\
\text { Health promotion program for female's reproduction, sex } \\
\text { education \& counseling program and PR, and operation of } \\
\text { breastfeeding clinic at health center }\end{array}$ & 1128 & 454,606 & $2,422,441$ \\
\hline $\begin{array}{l}\text { Dementia } \\
\text { management } \\
\qquad(9)\end{array}$ & $\begin{array}{c}\text { Operation of dementia counseling center } \\
\text { Early medical checkup project for dementia } \\
\text { Identification tag distributing project for loitering elderly } \\
\text { persons } \\
\text { Supporting treatment and management expense for } \\
\text { dementia }\end{array}$ & 978 & 719,673 & $1,375,672$ \\
\hline $\begin{array}{l}\text { Community-based } \\
\text { rehabilitation } \\
\text { (10) }\end{array}$ & $\begin{array}{c}\text { Rehabilitation project for the disabled } \\
\text { Social participation project for the disabled } \\
\text { Prevention project for second disorder } \\
\text { Building the community rehabilitation consultative group }\end{array}$ & 385 & 71,975 & 949,999 \\
\hline $\begin{array}{l}\text { Visiting health care } \\
\text { (11) }\end{array}$ & $\begin{array}{c}\text { Improvement of health behavior } \\
\text { Chronic disease management and complication prevention } \\
\text { Pregnancy, newborn baby, and infant care } \\
\text { Prevention of elderly weakness } \\
\text { Management of multicultural families and North Korean } \\
\text { defectors } \\
\text { Rehabilitation management for the disabled }\end{array}$ & 925 & $1,051,938$ & $4,878,154$ \\
\hline $\begin{array}{l}\text { Preventive } \\
\text { management of } \\
\text { atopy and asthma } \\
\text { (12) }\end{array}$ & $\begin{array}{c}\text { Running an atopy/asthma relief school } \\
\text { Supporting atopy and asthma patients for vulnerable social } \\
\text { groups } \\
\text { Education for atopy and asthma } \\
\text { Publicity on atopy and asthma }\end{array}$ & 147 & 130,814 & 130,814 \\
\hline $\begin{array}{l}\text { 9) Anti-smoking } \\
\text { campaign } \\
\text { (13) }\end{array}$ & $\begin{array}{l}\text { Prevention of smoking and promotion of anti-smoking } \\
\text { campaign }\end{array}$ & & - & \\
\hline
\end{tabular}

In the second place, nine projects have been conducted in addition to the community-integrated health projects, which include a mental health service, social welfare service for the aged, tuberculosis management, Hansen's disease management, sexually transmitted infection management, maternal and child health, and vaccination program. Among the other health promotion projects, the 306,415 people who participated in the health examination result counseling project accounted for the largest group, and it was determined that this is because various services are being provided through 3 times of project advancement. Second, it was found that 295,365 people were actually participating in mental health projects and were receiving various services related to mental health, addiction, and so forth. The people participating in health services for the elderly, tuberculosis management project, and so forth, took the next largest percentage (Table 3). 
Table 3. Projects other than community integrated health projects.

\begin{tabular}{|c|c|c|c|c|}
\hline & Project Contents & $\begin{array}{l}\text { Implementing } \\
\text { Agency }\end{array}$ & $\begin{array}{c}\text { Actual } \\
\text { User }\end{array}$ & Total Users \\
\hline $\begin{array}{l}\text { Mental health } \\
\text { project } \\
\text { (14) }\end{array}$ & $\begin{array}{l}\text { Establishment and operation of mental health promotion } \\
\text { center and fund support } \\
\text { Mental health project for child and youth } \\
\text { Mental health promotion project } \\
\text { Operating suicide prevention projects and suicide } \\
\text { prevention centers } \\
\text { Establishment and operation of addiction management } \\
\text { integrated support centers and fund support } \\
\text { Sound drinking project } \\
\text { Treatment and protection project for drug addicts } \\
\text { Project for prejudice relief and awareness improvement on } \\
\text { mental illness } \\
\text { Installation and operation of mental health project support } \\
\text { corps } \\
\text { Social rehabilitation facility establishment \& operation and } \\
\text { function reinforcing project } \\
\text { Mental health care facility establishment \& operation and } \\
\text { function reinforcing project } \\
\text { Establishment and operation of mental health medical } \\
\text { centers; protection of rights and interests for the } \\
\text { mentally-disordered people }\end{array}$ & 224 & 295,365 & 345,014 \\
\hline $\begin{array}{l}\text { Senile health } \\
\text { welfare project } \\
\qquad(15)\end{array}$ & $\begin{array}{l}\text { Senile medical checkup project } \\
\text { Senile ophthalmic checkup and eyesight recovery operation }\end{array}$ & 341 & 135,252 & 201,200 \\
\hline $\begin{array}{l}\text { Counseling on } \\
\text { medical } \\
\text { examination results } \\
(16)\end{array}$ & $\begin{array}{l}\text { Health counseling service } \\
\text { Follow-up checking of counseling on medical examination } \\
\text { results }\end{array}$ & 136 & 306,415 & 745,645 \\
\hline $\begin{array}{l}\text { False teeth } \\
\text { (dentures) project of } \\
\text { public health } \\
\text { centers } \\
\text { (17) }\end{array}$ & $\begin{array}{l}\text { Supporting procedure costs and follow-up expenses for } \\
\text { complete and partial dentures (false teeth) }\end{array}$ & 72 & 4347 & 5347 \\
\hline $\begin{array}{l}\text { Tuberculosis } \\
\text { management } \\
\qquad(18)\end{array}$ & $\begin{array}{l}\text { Tuberculosis checkup and reporting \& informing } \\
\text { Management and support for tuberculosis patients } \\
\text { Epidemiological survey for group facilities } \\
\text { Zoonotic tuberculosis management }\end{array}$ & 289 & 261,664 & 359,386 \\
\hline $\begin{array}{l}\text { Hansen's disease } \\
\text { management } \\
\text { (19) }\end{array}$ & $\begin{array}{l}\text { Case finding project } \\
\text { Hansen's disease project service } \\
\text { Diagnosis and treatment }\end{array}$ & 19 & 92 & 99 \\
\hline $\begin{array}{c}\text { Sexually } \\
\text { transmitted } \\
\text { infectious disease } \\
\text { control } \\
(20)\end{array}$ & $\begin{array}{l}\text { Sexually transmitted infectious disease control } \\
\text { Issuance of medical checkups and physical checkup results } \\
\text { (registration \& management of sexually transmitted } \\
\text { diseases, subjects, and the persons with opinions on } \\
\text { disease), support for treatment, establishment and } \\
\text { operation of exclusive clinics for sexually transmitted } \\
\text { diseases, education and promotion, and result reporting }\end{array}$ & 258 & 24,417 & 34,857 \\
\hline $\begin{array}{l}\text { Maternal and child } \\
\text { health project } \\
\qquad(21)\end{array}$ & $\begin{array}{l}\text { Medical expense support project for youth mother's } \\
\text { pregnancy and childbirth } \\
\text { Support project on surgical procedure costs for subfertility } \\
\text { couples } \\
\text { Registration management of premature babies and } \\
\text { congenital abnormal infants and support for medical } \\
\text { expenses etc. } \\
\text { Congenital metabolic abnormality test and patient child } \\
\text { management } \\
\text { Early diagnosis project of hearing loss } \\
\text { Blindness prevention project for preschool children }\end{array}$ & 444 & 77,232 & 84,558 \\
\hline Vaccination & Vaccination & 1535 & $1,430,321$ & $1,972,355$ \\
\hline
\end{tabular}

\section{Results}

\subsection{Data Utilization Status for PHIS}

The Social Security Information Service is operating various social security-related systems, including the Regional Public Health Information System, the pan-government system, the facility management system, the vulnerable old man system, and so forth, as well as the social security information system. Among these, the Regional Public Health Information System is a system for 
implementing the medical treatment administration, health service, public health administrations, and so on of various regional health and medical institutions, such as public health centers, branch offices of health centers, health care centers, and so forth, having a huge amount of data. The Regional Public Health Information System is not only linked to its own system, but also to various systems, whose status is shown as follows. The PHIS in the SSIS was utilizing a total of nine data sets related to the project: health care Data Warehouse (DW), common items, medical treatment, civil affair administration, health promotion, nutrition plus, tuberculosis control, vaccination, and the elderly. The systems linked with the PHIS were three pan-government systems, Hangbok-e-eum, and the vulnerable old man system in the SSIS, whose data was sent to and received by each system. In addition to that, it was connected to a total of 10 systems, including the Korea Centers for Disease Control and Prevention, the Korea Health Industry Development Institution, the National Health Insurance Corporation, health agencies, the credit card van company, the Korea Association for ICT Promotion (KAIT), the Ministry of Public Administration and Security, emergency medical centers, the case management system, and the joint evaluation system.

Among the linked institutions, the institution that sends the most data has sent 15 cases to the Social Security Information System (Hangbok-e-eum) as the common item; the health care DW has received the data of 70 cases from the Social Security Information System (Hangbok-e-eum). Specifically, the data utilization status is shown in Figure 2.

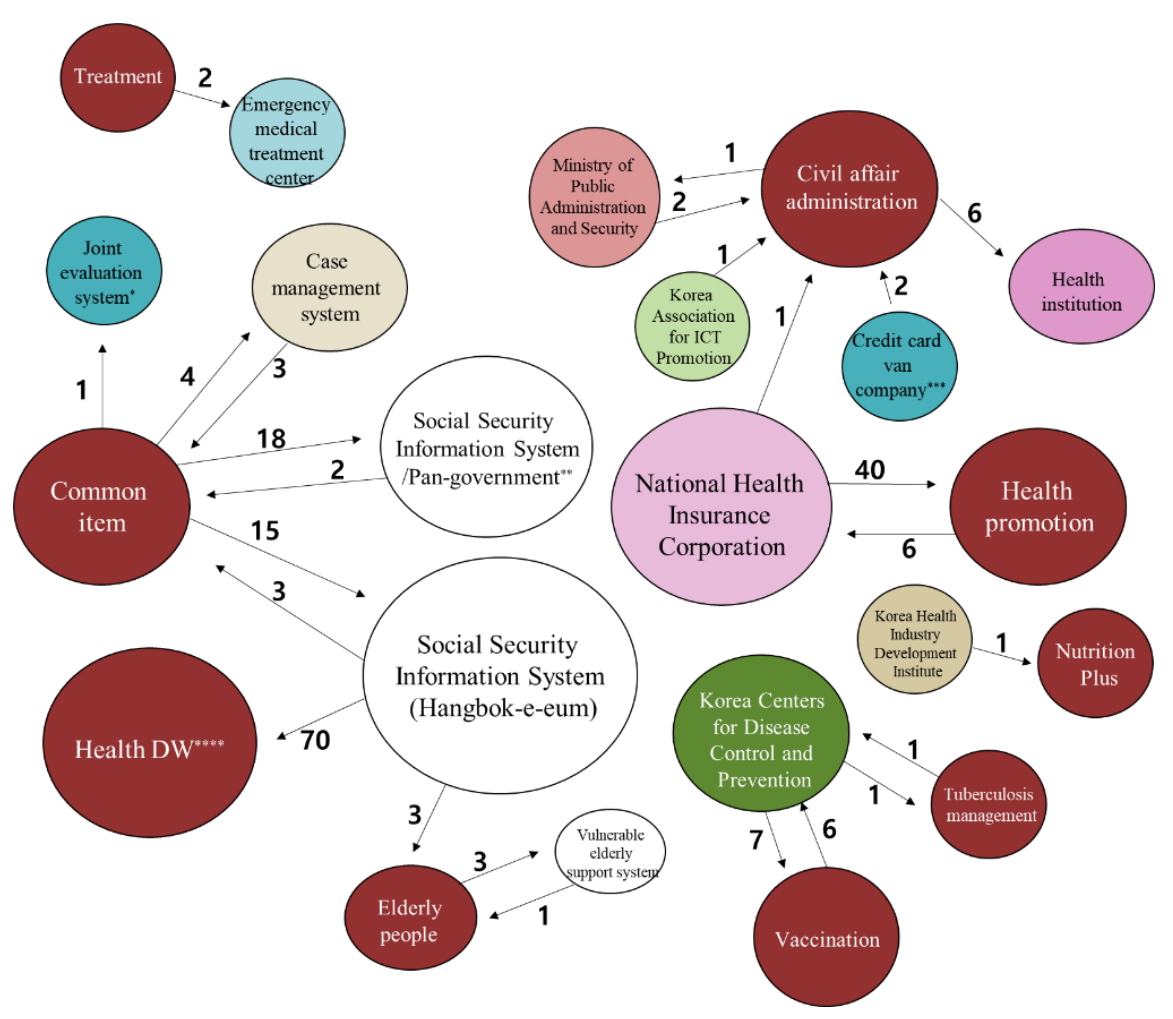

Figure 2. Data linkage status of health promotion projects within the Public Health Information System (PHIS). * The joint evaluation system is a joint system to evaluate the business performance of local governments. ${ }^{* *}$ The pan-government system is a system to integrate and manage the welfare project information, qualification information of benefit recipients, and reception history information, provided by each government department and information holding institution. ${ }^{* * *}$ Credit card van companies are institutions that do business related to payment for it and receive commissions, in the process that the benefit recipients make payments with their credit cards and then the government pays them. **** The Data Warehouse (DW) in the Regional PHIS refers to the system space that the government stores data in an analyzable form for rational policy making, based on the original data accumulated in the PHIS. 
First, the health promotion-related data in the PHIS is being sent to and received by the National Health Insurance Service. A total of 40 cases were received from the National Health Insurance Service by the PHIS, whereas the data of only six cases have been sent to the National Health Insurance Service, where received data was mainly on medical care and infant health examinations.

Second, the Hangbok-e-eum in the Social Security Information System has sent a total of 70 cases to the PHIS DW, but no data has been received from it. Most of the data received was diverse and included National Basic Livelihood Security, basic pension, disability pension, disability allowance, child welfare, infant care, welfare facilities, and so forth, which were connected with the PHIS.

Third, the system connected with common items included various systems, such as Hangbok-e-eum, the case management system, pan-government system, and joint evaluation system. First, examining the status of where common items in the PHIS became linked to Hangbok-e-eum, all were transmitted data related to critical households at public health centers. Common items and pan-government systems are mutually linked to each other in their transmitting and receiving, which had 18 cases of transmission and two cases of reception. In the meantime, the transmitted data were very diverse on regional rehabilitation projects, maternal and child health, dementia, newborns, Hansen people, and so forth, while the received data were limited to fraud and changed information. The connection status between common items in the PHIS and the case management system showed four transmissions and three receptions. The transmitted data included the service list of public health centers, the service requests, and so forth, and the received data were related to case management and counseling. The linkage between the common items in the PHIS and the data in the joint evaluation system included only one transmission related to the government-run joint evaluation visiting health project.

Fourth, the vaccinations in the PHIS were linked with data from the vaccination linkage system in the Korea Centers for Disease Control and Prevention, with six cases of transmitted data and seven cases of received data, which were mainly related to vaccination.

Fifth, in relation to the civil affairs administration in the PHIS, data linkages have been made with various agencies, such as the Ministry of Public Administration and Security, the Korea Association for ICT Promotion (KAIT), the National Health Insurance Corporation, credit card van companies, and health agencies. The data linkage between the civil affairs administration and the Public Information Sharing Center in the Ministry of Public Administration and Security was found to include one transmission and two receptions, where the transmitted data were the medical examination results and the received data were resident information and road name addresses. The linkage between the civil affairs administration and the foreigners' real name verification system of the Korea Association for ICT Promotion (KAIT) had one case of received data, which was the foreigners' real name verification data. In connection with the insurance qualification inquiry web service of the National Health Insurance Corporation, one case was being received with respect to the insurance type and qualification inquiry for the objects. The data linkage between the civil affairs administration and the credit card approval system of the credit card van companies included two cases of the received data, including card bundle approval and deposit-returning linkage, and only five transmissions were linked with unmanned issuers in the health agencies, including vaccination certificates, general medical examination reports, medical examination results, and so forth.

Sixth, the data related to the elderly in the PHIS were linked with the vulnerable elderly support system and the Social Security Information System (Hangbok-e-eum). There were data linkages of three transmissions and one reception with the vulnerable elderly support system, where the transmission went for personal information of dementia subjects, application for the issue of identification tag, and examination information, and the reception was the issuing result of dementia identification tags. The data linkage with Hangbok-e-eum sound was found to be only three receptions: basic living recipient information, near-poverty group information, and single parent information.

Seventh, the tuberculosis management project in the PHIS had a data linkage with the integrated tuberculosis information management system of the Korea Centers for Disease Control and Prevention, 
including one transmission related to the TB test request and one reception with respect to the TB test result.

Eighth, in relation to the Nutrition Plus project in the PHIS, data was linked with the Nutrition Plus system in the Korea Health Industry Development Institute, where there was only one case of received information related to nutrient intake.

Ninth, two cases of transmission were linked to each other between the treatment and emergency medical care centers in the PHIS, including the real-time transmission of sickbed information and emergency patient care-related information.

Putting the above linkage statuses together, the PHIS showed the least data utilization related to the project. Therefore, we could determine that it is desperately in need of utilizing data that can actually improve the health levels of the people rather than systemic linkage. Additionally, the health promotion project system should be developed into a system for managing individual health information, and not just a space for storing or accumulating information.

\subsection{Effectiveness of the Counseling Program for Health Examination Results}

As examined earlier, even though they have accumulated a large amount of data, the PHIS has not improved its effectiveness by using it. Accordingly, since February 2019, the Social Security Information Service with the National Health Insurance Corporation has been providing individual guides for those who have been suspected of having diseases as a result of individual health checkups, in order for them to get health checkups and medical treatment at relevant public health centers (branch offices). In order to increase the effectiveness of the guidance on health checkup results, the Social Security Information Service has developed and complemented a function for managing suspicious patients in the PHIS to take measures so that those who have health problems can be quickly examined. As a primary measure, it has improved the counseling screening used by health care medical teams to enable customized health counseling.

Second, the counseling program added the function of utilizing the results of health examinations when conducting the health promotion projects that will expand in the future, including cardio-cerebrovascular disease projects, oriental medicine health promotion projects, and so forth. In addition, in terms of the guiding methods for medical examination results, it adopted various interactive methods via text messages and mail, along with telephone and face-to-face deliveries. The health examination items were subdivided into 82 units, making it easier to make intensive management for each disease. In the third round, access and inquiries were enabled into information from health examination results even in the health care centers, and the health examination inquiry function was also added to the visiting health management and community-based rehabilitation projects.

As of the end of December 2019, local residents using regional health and medical institutions were $60,533,042$ people as the total users for 3566 institutions and 7,426,843 people as the actual users in the whole population are participating in the health promotion project (Social Security Information Service; www.ssis.or.kr). For the health examination result counseling service among them, 201,200 people are annually using it at 136 regional health and medical institutions (public health centers, branch offices of health center, etc.). Due to the activation of counseling services for health examination results, the proportion of guiding objects out of the 3.6 million linked cases as of 2018 was only $4.7 \%$, but since the secondary improvement project in 2019, the trend has sharply increased compared to that of the previous year. June 2019, the number of cumulative cases as the guiding objects of the health examination result has rapidly surpassed the results of the previous year.

Specifically, as of October 2019, the results from the expansion of health examination result counseling services were as follows. First, the excavating rate of follow-up management objects, compared to the number of linked cases with the health examination results, also increased from $4.7 \%$ in the previous year to $7.3 \%$ as of October 2019 , which shows that it actually plays a role in the health of local residents. 
Second, investigating users' features, the utilization rate of men was $56.9 \%$ higher than that of women, and the utilization rate appeared to be higher in people from their forties to sixties. In addition, for those who used guiding services, those whose health examination was normal but who needed preventive measures totaled 107,736 people, accounting for the greatest percentage, followed by 66,130 people who were suspected patients of general diseases, 41,935 patients who had diseases, and 22,963 people suspected of having hypertension and diabetes. This result shows that out of the total recipients of guiding health examination results, more services are being provided for those who are healthy but need to take preventive action than for those who already have a disease.

Third, the proportion of elderly objects was lower in rural and fishing areas, where the ratio of serviced subjects to the number of cases linked to the health examination result counseling appeared high. On the other hand, in the case of metropolises, the proportion of the elderly among the subjects was high, even though the ratio of the service guiding objects to the number of linked cases might be low (Table 4).

Table 4. Proportion of guiding service objects and elderly objects by city and province.

\begin{tabular}{|c|c|c|c|c|c|c|c|c|c|c|c|c|c|c|}
\hline \multirow[t]{2}{*}{ City and Province } & \multicolumn{7}{|c|}{ Metropolitan Areas, such as Seoul, Busan, Incheon, etc. } & \multicolumn{7}{|c|}{$\begin{array}{l}\text { Urban and Rural Complex Areas, such as } \\
\text { Gangwon, Jeonnam, Gyeongbuk, etc. }\end{array}$} \\
\hline & ${ }^{*} \mathbf{A}$ & B & $\mathrm{C}$ & D & $\mathrm{E}$ & $\mathbf{F}$ & G & $\mathbf{H}$ & I & $\mathbf{J}$ & K & L & $\mathbf{M}$ & $\mathbf{N}$ \\
\hline${ }^{* *}$ Ratio & 2.96 & 2.19 & 2.1 & 1.62 & 0.62 & 0.46 & 0.38 & 17.6 & 13.74 & 13.55 & 9.34 & 9.18 & 9.17 & 8.02 \\
\hline$* * *$ Ratio of Elderly & 55.01 & 73.57 & 60.31 & 41.43 & 63.77 & 83.92 & 71.8 & 36.45 & 25.02 & 23.91 & 35.72 & 24.41 & 30.3 & 38.02 \\
\hline
\end{tabular}

Therefore, if the health examination result counseling service expands, in the case of farming and fishing areas, it is highly likely to become a universal service for all local residents including the elderly. In other words, if the health examination result counseling project expands, in the farming and fishing areas where medical institutions and medical resources are scarce, it is expected to fill the role of a true primary care provider by performing health programs, such as oriental medicine health promotion projects, cardio-cerebrovascular disease projects, and so forth, for all local residents, based on the results of health examinations centered on the branch offices of health centers and health care centers. In particular, health agencies with only 29 locations in Seoul, 32 in Busan, and 25 in Daegu have 562 locations in Jeonnam, 559 in Gyeongbuk, and 416 in Gyeongnam, which shows a high proportion of their locations. Therefore, there is no choice but to emphasize the role of public health and medical institutions over general private medical institutions.

\section{Discussion}

The purpose of this study is to analyze the status of linked actions with health promotion data on the PHIS and the results of the project to provide the health examination result counseling service to local residents through the linked actions. The results of the analysis are as follows: First, we reviewed the status of 22 health promotion projects, including 13 integrated health promotion projects and 9 other health promotion projects, which use the social security information system as the information systems for health promotion services. In addition, we also examined how the 22 projects were becoming linked with other health promotion systems. Despite the vast amount of data accumulated, only 10 projects were linked to the health promotion data of the health and medical information system, except for the system of the SSIS.

Second, we investigated the results of the health examination result counseling service via the linkage with health promotion data. It was found that it was effective when the regional health and medical institutions (public health centers) use the PHIS to perform health promotion projects by linking the health examination results of the National Health Insurance Corporation. In other words, when the health promotion data were linked, the number of follow-up management objects of health 
examination increased, and the project could be activated, centered on farming and fishing villages where medical infrastructure was insufficient.

Based on these analysis results, the policy considerations for the future health promotion project are as follows: First, it is necessary to understand the status of various institutions, related to health promotion, and information systems which those institutions operate, to categorize the health promotion projects that need to be linked with each other, and to strengthen collaboration between project entities. Second, in the farming and fishing villages which lack private medical institutions, it is necessary to adjust the priority of health promotion projects according to local characteristics. Third, for the projects that could achieve some results through linkages, it is needed to reinforce the effectiveness by unify their project entities.

Consequently, the health examination result counseling program of local health and medical institutions should be activated in rural areas where the proportion of private medical institutions is lower compared to the total number of medical institutions and public health centers (branch offices), and health care centers should assume the role of primary care institutions. This will lead to the reinforcement of medical governance, such as the Ministry of Health and Welfare, local governments, local health agencies, and the Social Security Information Service, thereby resolving medical blind spots. In particular, the Social Security Information Service, which runs the Regional Public Health System that is generally managing the health promotion project, medical treatment service, and health administration of regional public health institutions, will have to play a pivotal role as a data platform.

\section{Conclusions}

This study has significance as a study which examined the status of data-linked utilization by analyzing the regional public health information system which has been used as a system to operate health promotion projects for over 10 years and then identified the effectiveness of the project through data linkage. However, it actually has a limitation in understanding the broader linked status with various health-related systems other than PHIS; furthermore, we hope that the follow-up study will be able to structure projects for performing efficient health promotion projects and that new projects considering the regional characteristics will be suggested.

Author Contributions: Data curation, S.C.; Formal analysis, K.Y.; Methodology, S.P.; Project administration, M.L.; Writing-original draft, K.Y.; Writing—review \& editing, M.L. All authors have read and agreed to the published version of the manuscript.

Funding: This work was supported by the Ministry of Education of the Republic of Korea and the National Research Foundation of Korea (NRF-2019S1A5A2A03040304).

Acknowledgments: We thank the Social Security Information Service for the research.

Conflicts of Interest: The author declares no conflict of interest.

\section{References}

1. Schonberg, M.A.; Li, V.; Marcantonio, E.R.; Davis, R.B.; McCarthy, E.P. Predicting Mortality up to 14 Years Among Community-Dwelling Adults Aged 65 and Older. J. Am. Geriatr. Soc. 2017, 65, 1310-1315. [CrossRef] [PubMed]

2. Kontis, V.; Bennett, J.E.; Mathers, C.D.; Li, G.; Foreman, K.; Ezzati, M. Future life expectancy in 35 industrialised countries: Projections with a Bayesian model ensemble. Lancet 2017, 389, 1323-1335. [CrossRef]

3. Tengland, P.-A. Behavior change or empowerment: On the ethics of health-promotion goals. Health Care Anal. 2016, 24, 24-46. [CrossRef] [PubMed]

4. Pykett, J. Healthy Nations: Behavioural Approaches in Public Health Policy. In Behavioural Policies for Health Promotion and Disease Prevention; Springer: Berlin/Heidelberg, Germany, 2019; pp. 53-72.

5. Green, A.; Ross, D.; Mirzoev, T. Primary health care and England: the coming of age of Alma Ata? Health Policy 2007, 80, 11-31.

6. Hone, T.; Macinko, J.; Millett, C. Revisiting Alma-Ata: What is the role of primary health care in achieving the Sustainable Development Goals? Lancet 2018, 392, 1461-1472. [CrossRef] 
7. Chokshi, D.A.; Cohen, L. Progress in primary care-From Alma-Ata to Astana. JAMA 2018, 320, $1965-1966$. [CrossRef]

8. Hwang, W.J.; Park, Y.M. Factors Influencing the Accessibility of Maternal Health Service in Cambodia. Int. J. Environ. Res. Public Health 2019, 16, 2909. [CrossRef]

9. Kirby, J.B.; Yabroff, K.R. Rural-Urban Differences in Access to Primary Care: Beyond the Usual Source of Care Provider. Am. J. Prev. Med. 2020, 58, 89-96. [CrossRef]

10. Weigel, P.A.; Ullrich, F.; Shane, D.M.; Mueller, K.J. Variation in primary care service patterns by rural-urban location. J. Rural Health 2016, 32, 196-203. [CrossRef]

11. Mc Grath, M.; Clancy, K.; Kenny, A. An exploration of strategies used by older people to obtain information about health-and social care services in the community. Health Expect. 2016, 19, 1150-1159. [CrossRef]

12. Lee, M.; Park, S.; Yoon, K. Does Health Promotion Program Affect Local Resident'Emotions? Int. J. Environ. Res. Public Health 2019, 16, 549. [CrossRef]

13. Hatef, E.; Weiner, J.P.; Kharrazi, H. A public health perspective on using electronic health records to address social determinants of health: The potential for a national system of local community health records in the United States. Int. J. Med. Inform. 2019, 124, 86-89. [CrossRef] [PubMed]

14. Ozano, K.; Simkhada, P.; Thann, K.; Khatri, R. Improving local health through community health workers in Cambodia: Challenges and solutions. Hum. Resour. Health 2018, 16, 2. [CrossRef] [PubMed]

15. Estacio, E.V.; Oliver, M.; Downing, B.; Kurth, J.; Protheroe, J. Effective partnership in community-based health promotion: Lessons from the health literacy partnership. Int. J. Environ. Res. Public Health 2017, 14, 1550. [CrossRef] [PubMed]

16. Lee, M.; Yoon, K. Effects of the Health Promotion Programs on Happiness. Sustainability 2020, $12,528$. [CrossRef]

17. Christodoulou, G.N.; Rutz, W.; Herrman, H.; Christodoulou, N.G.; Schmolke, M. Person-Centered Mental Health Promotion and Public Health perspectives. In Person Centered Psychiatry; Springer: Berlin/Heidelberg, Germany, 2016; pp. 291-306.

18. Gagné, T.; Lapalme, J.; McQueen, D.V. Multidisciplinarity in health promotion: A bibliometric analysis of current research. Health Promot. Int. 2018, 33, 610-621. [CrossRef]

19. Fry, D.; Zask, A. Applying the Ottawa Charter to inform health promotion programme design. Health Promot. Int. 2017, 32, 901-912. [CrossRef]

20. Keleher, H.; MacDougall, C. Understanding Health; Oxford University Press: Oxford, UK, 2015.

21. Adler, N.E.; Glymour, M.M.; Fielding, J. Addressing social determinants of health and health inequalities. JAMA 2016, 316, 1641-1642. [CrossRef]

22. Williams, D.M.; Rhodes, R.E.; Conner, M.T. Conceptualizing and Intervening on Affective Determinants of Health Behavior; Taylor \& Francis: Abingdon, UK, 2019.

23. Thompson, S.; Watson, M.; Tilford, S. The Ottawa Charter 30 years on: Still an important standard for health promotion. Int. J. Health Promot. Educ. 2018, 56, 73-84. [CrossRef]

24. Weiss, D.; Lillefjell, M.; Magnus, E. Facilitators for the development and implementation of health promoting policy and programs-A scoping review at the local community level. BMC Public Health 2016, 16, 140. [CrossRef]

25. Vuori, I. Experiences from the European network for the promotion of health-enhancing physical activity (European HEPA Network). Ongoing Act. Exp. Eur. Glob. Level 2014, 9.

26. Magnus, E.; Knudtsen, M.S.; Wist, G.; Weiss, D.; Lillefjell, M. The search conference as a method in planning community health promotion actions. J. Public Health Res. 2016, 5, 621. [CrossRef] [PubMed]

27. Trinh-Shevrin, C.; Nadkarni, S.; Park, R.; Islam, N.; Kwon, S.C. Defining an integrative approach for health promotion and disease prevention: A population health equity framework. J. Health Care Poor Underserved 2015, 26, 146. [CrossRef] [PubMed]

28. Paek, J.-S.; Hong, S. A study on the evaluation and improvement of an integrated health promotion program in the local community. J. Korea Converg. Soc. 2017, 8, 131-139.

29. Yoo, S. Photovoice as a research method and a strategy for community health promotion. Korean J. Health Educ. Promot. 2015, 32, 77-87. [CrossRef]

30. Song, Y.-K.; Kim, J.H.; Choi, B.; Han, N.; Kim, M.G.; Lee, J.; Lee, H.; Yoon, J.; Lee, B.-J.; Oh, J.M. Strategic priorities to improve effectiveness of anti-smoking interventions for the Korean military: An application of the analytic hierarchy process. Mil. Med. 2018, 183, e223-e230. [CrossRef] 
31. Lee, G.; Yang, S.-J.; Woo, E. Past, present, and future of home visiting healthcare services based on public health centers in Korea. J. Korean Public Health Nurs. 2018, 32, 5-18.

32. Pons-Vigués, M.; Berenguera, A.; Coma-Auli, N.; Pombo-Ramos, H.; March, S.; Asensio-Martínez, A.; Moreno-Peral, P.; Mora-Simón, S.; Martínez-Andrés, M.; Pujol-Ribera, E. Health-care users, key community informants and primary health care workers' views on health, health promotion, health assets and deficits: Qualitative study in seven Spanish regions. Int. J. Equity Health 2017, 16, 99. [CrossRef]

33. Carstensen, K.; Brostrøm Kousgaard, M.; Burau, V. Sustaining an intervention for physical health promotion in community mental health services: A multisite case study. Health Soc. Care Community 2019, 27, 502-515. [CrossRef]

34. Burau, V.; Carstensen, K.; Fredens, M.; Kousgaard, M.B. Exploring drivers and challenges in implementation of health promotion in community mental health services: A qualitative multi-site case study using normalization process theory. BMC Health Serv. Res. 2018, 18, 36. [CrossRef]

35. Seo, K.; Kim, H.-N.; Kim, H. Current Status of the Adoption, Utilization and Helpfulness of Health Information Systems in Korea. Int. J. Environ. Res. Public Health 2019, 16, 2122. [CrossRef]

(C) 2020 by the authors. Licensee MDPI, Basel, Switzerland. This article is an open access article distributed under the terms and conditions of the Creative Commons Attribution (CC BY) license (http://creativecommons.org/licenses/by/4.0/). 